\title{
Chapter 42: Legitimacy has risks and benefits for effective international marine management
}

Lisa Maria Dellmuth, Stockholm University (Lisa.dellmuth@su.se)

In: Predicting Future Oceans: Sustainability of Ocean and Human Systems Amidst Global Environmental Change, ed. by Andrés M. Cisneros-Montemayor, William W.L. Cheung, and Yoshitaka Ota. Elsevier, 2019.

\subsection{Introduction}

One of the most nagging criticisms of international marine institutions has been their mixed track record in effectively protecting biodiversity [1] and managing highly migratory and straddling fish stocks [2]. This variation in effectiveness has fueled social science scholarship on the sources of effective marine management. Both in sustainability science $[3,4]$ and political science $[5,6]$, informational, financial, and organizational factors are consistently highlighted as central drivers of effectiveness.

This chapter focuses on a factor that much social science scholarship connects with compliance and thus more effective institutions: legitimacy [7,10]. A legitimate institution enjoys public trust, which may increase compliance with its rules and decrease investment of scarce resources in coercion and enforcement through, for example, fines or sanctions [11].

Most sustainability research is exclusively concerned with the drivers of effectiveness in international marine institutions in terms of the potentially positive effects of "collaborative management" [12]. Participation in management by nongovernmental organizations (NGOs) and other stakeholders such as end users of resources has been shown to improve the processes [13,14], reform capacity $[15,16]$, and problem-solving capacity $[3,17]$ of international marine institutions. In addition, comanagement has been argued to foster trust and cooperative behavior in international institutions [18]. Despite this progress, we still know little about how legitimacy could be useful - or detrimental - in the quest for improved marine management. 
To contribute to this endeavor, this chapter argues that legitimacy may be a resource for more effective marine management, but that it comes with risks. Legitimacy is a great social good. Building on early contributions in sociology [19], political scientists have suggested that legitimacy fosters human happiness as people prefer to comply with institutions on moral grounds and not for reasons of self-interest [20]. A number of previous studies suggest that international institutions should attend to their legitimacy in order to increase their viability and effectiveness $[11,21,22]$. However, while legitimacy certainly contributes to compliance, a large literature in political science alludes to the risks of declining public scrutiny and greater influence of special interest groups. The remainder of this chapter is as follows. First, it defines legitimacy, drawing from political science literature. Second, it illustrates legitimacy patterns in 19 international marine institutions by drawing on original data from an expert survey among more than 300 natural and social scientists and practitioners. Third, it discusses which potential benefits and risks legitimacy may engender in international marine management. By way of conclusion, the chapter outlines a research agenda for sustainability scholars on legitimacy and effectiveness.

\subsection{Defining legitimacy as beliefs}

Legitimacy refers to the degree of individual beliefs among the subjects of a political institution that this institution's authority is appropriately exercised $[19,22]$. Legitimacy in this sense refers to beliefs in sociological terms and not on, whether, in normative terms, global institutions conform to philosophical standards such as fairness or justice. While most literature in International Relations (IR) deals with normative legitimacy [21,23,24], sociological legitimacy has increasingly attracted scholarly attention in recent years $[22,25,26]$.

Legitimacy is a matter of degrees. Actors such as individuals, NGOs, or states may hold legitimacy beliefs to varying extents because they believe in the moral rightfulness of a political institution [26,27]. Political scientists have debated this definition in terms of whether legitimacy beliefs are exclusively grounded in moral beliefs or whether they also reflect personal self-interest. Indeed in today's more global world, international organizations often visibly affect individual lives, making it likely that individuals

hold international institutions accountable both on grounds of moral conviction and self-interest [28].

\subsection{The legitimacy of international marine institutions}


A recent study examines legitimacy perceptions of institutions addressing fisheries and marine issues that are central hubs in their respective issue areas. ${ }^{1}$ Existing political science literature derives legitimacy measures through a variety of methods, such as content analysis of debates in international institutions [29] or newswires [30], and public opinion polls [26]. In contrast to these methods, expert surveys are cost-efficient data collection efforts that yield comparable measures of legitimacy perceptions of different stakeholders. Because expert surveys do not require access to voting records or documents, this method can be applied to any institution in the world.

\subsubsection{Research design}

This study focuses on the extent to which states, NGOs, citizens, and experts trust a number of international institutions whose actions are consequential for domestic and transnational marine management: United Nations (UN) agencies, partnerships, regional organizations, and development banks (see Table 42.1). These institutions are central hubs in their respective issue areas and all deal with marine management. Data were gathered through an online survey fielded between January and April 2018 among natural and social scientists in the academic and practitioner community.

Experts were selected in two steps. First, the starting point for identifying experts was Google Scholar, programs of central academic IR and political science conferences, and the environmental social science networks "Earth System Governance" and "Mistra Geopolitics." Second, we selected experts that come from a variety of cultural backgrounds (48 countries) and that have firsthand knowledge of the marine institutions based on research or collaboration. We made this assessment based on publication records, work descriptions, and in the case of limited information from these sources by asking the experts. Consequently, legitimacy assessments are made by experts from different cultural backgrounds and largely reflect respondents' personal opinion and not exclusively information retrieved from the media. The average completion rate was $37 \%$ (see Appendix A).

\footnotetext{
${ }^{1}$ This data collection was designed and conducted with Dr. Maria-Therese Gustafsson at Stockholm University.
} 
Table 42.1: List of international institutions included in the survey.

\begin{tabular}{|c|c|c|c|c|}
\hline International organization & Acronym & Questionnaire & $\begin{array}{l}\text { Founding } \\
\text { year }\end{array}$ & Number of member states \\
\hline $\begin{array}{l}\text { Arctic CouncilAsian Development } \\
\text { Bank African Development Bank } \\
\text { Association of Southeast Asian } \\
\text { NationsEuropean Bank for } \\
\text { Reconstruction and } \\
\text { DevelopmentEuropean UnionFood } \\
\text { and Agriculture OrganizationGlobal } \\
\text { Environment Facility } \\
\text { Intergovernmental Panel on Climate } \\
\text { Change Organization for Economic } \\
\text { Co-operation and } \\
\text { DevelopmentPacific Islands Forum } \\
\text { South Asian Association for Regional } \\
\text { CooperationSouth Asia Co-operative } \\
\text { Environment Program United } \\
\text { Nations Development Programme } \\
\text { United Nations Environment } \\
\text { United Nations Framework } \\
\text { Convention on Climate ChangeUnion } \\
\text { of South American Nations } \\
\text { World BankWorld Health } \\
\text { Organization }\end{array}$ & $\begin{array}{l}\text { AC ADB } \\
\text { AFDB ASEAN } \\
\text { EBRD } \\
\text { EU FAO } \\
\text { GEF IPCC } \\
\text { OECD } \\
\text { PIF SAARC } \\
\text { SACEP UNDP } \\
\text { UN } \\
\text { Environment } \\
\text { UNFCCC } \\
\text { UNASUR } \\
\text { World Bank } \\
\text { WHO }\end{array}$ & $\begin{array}{l}\text { SingleSingleSingl } \\
\text { eAsian } \\
\text { organizations } \\
\text { Single } \\
\text { Single Single } \\
\text { Environment } \\
\text { Environment } \\
\text { Development } \\
\text { Asian } \\
\text { organizations } \\
\text { Asian } \\
\text { organizations } \\
\text { Asian } \\
\text { organizations } \\
\text { Development } \\
\text { organizations } \\
\text { Single } \\
\text { Environment } \\
\text { South American } \\
\text { organizations } \\
\text { World Bank } \\
\text { Single }\end{array}$ & $\begin{array}{l}1996 \\
1966 \\
1964 \\
1967 \\
1991 \\
19511945 \\
19921988 \\
1961 \\
1971 \\
1985 \\
1983 \\
1965 \\
1972 \\
1992 \\
2004 \\
19461946\end{array}$ & $\begin{array}{l}8488110 \\
66 \text { member states, including the EU and } \\
\text { the European Investment Bank27 } \\
191 \\
183195 \\
34 \\
1688193 \text { (UN) } 193 \text { (UN) } 165 \\
12 \\
185193\end{array}$ \\
\hline
\end{tabular}

Source: Organizations' websites. Several natural and social scientists in our survey had expertise on more than one international institution. In these cases, we bundled institutions in one questionnaires and block-randomized the order in which the questions on a specific institution occur. 
The online survey took about 5 minutes. For each institution, about 25 experts with knowledge on that specific institution were asked to rate legitimacy beliefs among different stakeholders toward that institution ("In your opinion, how much confidence do different stakeholders have in the Arctic Council?" see Appendix B). The study includes researchers affiliated with universities, research institutions, and think tanks. Think tank researchers only make up 10\% of the sample, as they may be more partial compared to other types of experts. However, researchers at think tanks often work closely with international institutions and have firsthand information of meetings and internal documents, making them valuable knowledge sources.

Measures for legitimacy beliefs are four-point confidence scales inspired by the World Values Survey and range from 0 (no confidence at all), 1 (not very much confidence),2 (quite a lot of confidence), to 3 (a great deal confidence). Where survey responses for member state confidence were split between member states in the global south and the global north, an average was produced to create one response (see Appendix B). Confidence measures are common in public opinion research on legitimacy. Importantly, "confidence" is a better measure than "support," as the latter can direct attention away from the underlying confidence in a political system and toward satisfaction with short-term distributional consequences [31]. The confidence measure was tested for scale reliability, and these checks vouch for the quality of the expert ratings (see Appendix C).

42.3.2 Key findings

Analyzing expert judgments of stakeholder confidence yields two key findings. First, Fig. 42.1 presents the variation in legitimacy perceptions across stakeholders. While the median citizen does not have very much confidence in institutions, the median elite (member states, NGO, and experts) has quite a lot of confidence. This suggests that there is a gap between how citizens and elites perceive international marine institutions. This finding corroborates previous insights on gaps between mass and elite opinion about politics more generally [32].

Second, the extent to which there is an elite!citizen gap in legitimacy beliefs differs between marine institutions (Fig. 42.2). The results suggest that member states on average have quite a lot or a great deal of confidence in the United Nations Framework Convention on Climate Change (UNFCCC) and Intergovernmental Panel on Climate Change (IPCC), most development banks, Arctic Council, Association of Southeast Asian Nations, European Union (EU), and Pacific Islands Forum. By contrast, NGOs and citizens have much lower 
confidence levels, with NGOs only having a mean confidence of quite a lot or a great deal in IPCC, and citizens only having a mean confidence of quite a lot or a great deal in WHO. Finally, experts themselves indicate an average confidence of quite a lot or a great deal in the UNFCCC and IPCC, some development banks, Arctic Council, and the EU. While citizen confidence on average is weaker than elite confidence, it is particularly low for South Asia Co-operative Environment Program, European Bank for Reconstruction and Development, and South Asian Association for Regional Cooperation (SAARC).

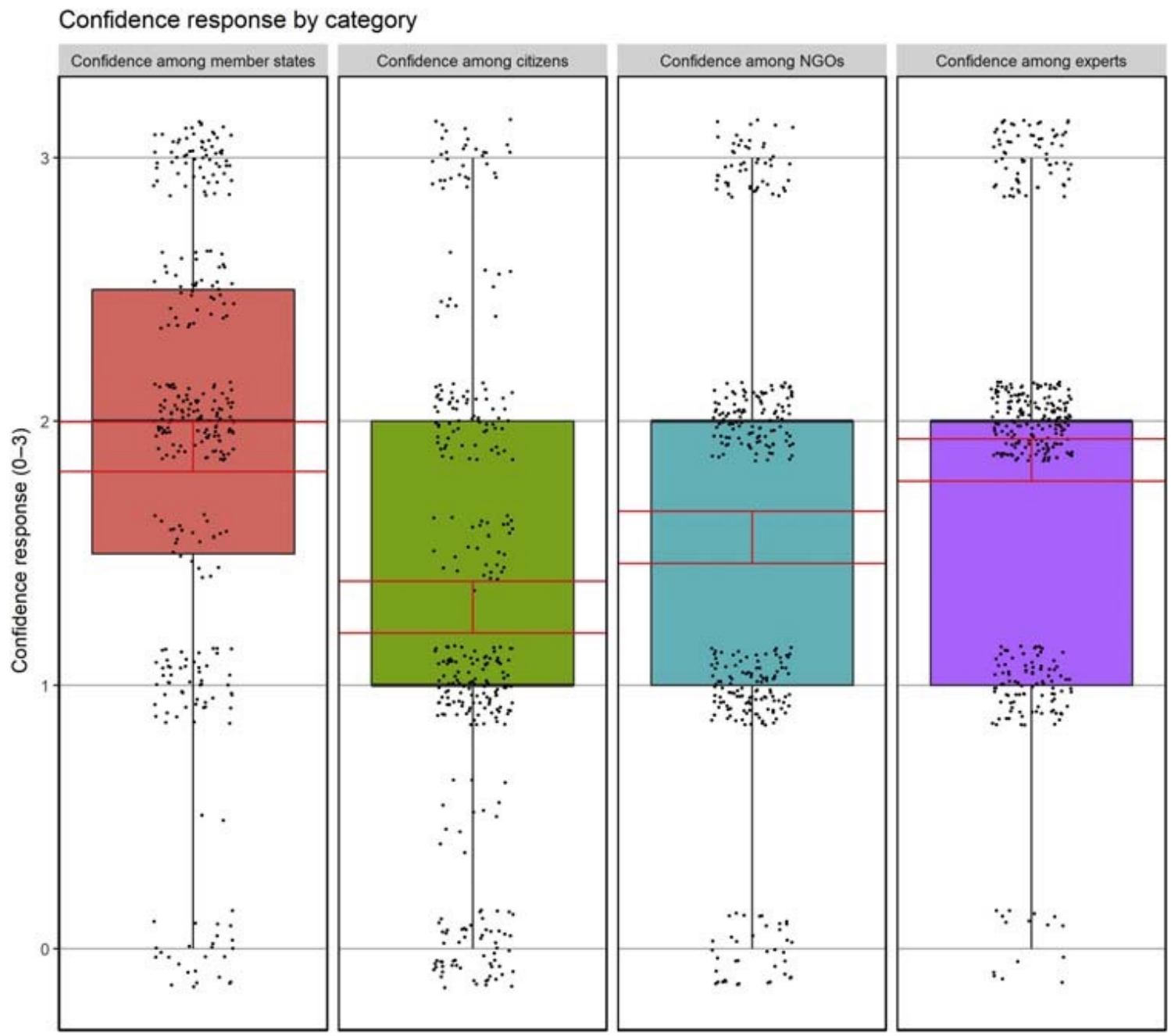

Figure 42.1: Confidence in international institutions across stakeholders. 0 (no confidence at all), 1 (not very much confidence), 2 (quite a lot of confidence), 3 (a great deal confidence). The red lines represent the $95 \%$ confidence interval, and the boxes show the interquartile range of observations. The horizontal thick black line shows the median. The point clusters depict individual expert ratings of the different audiences' legitimacy beliefs across the confidence scale N 5478 . 
These patterns indicate different legitimacy challenges for the different institutions. To begin with, elites have more confidence in development and health institutions than citizens with the exception of the WHO. Among institutions with a mandate in environmental affairs, the elite!citizen gap is less visible, which is in line with recent evidence from public opinion research. Over the past decade, exposure to several publicly salient UN climate summits may have rendered citizens on average more aware of UN activities on climate change [33] and therefore also more critical toward climate institutions than, for example, security and finance institutions [34]. Interestingly, experts tend to be critical toward all rated environmental institutions, which could be due to ongoing debates about the ability of global institutions to limit global warming to safe levels in a "post-Paris world" $[35,36]$. In financial affairs, citizens and NGOs are most critical and member states least critical, with some exceptions. The African Development Bank enjoys quite a lot of confidence among citizens and member states but is viewed rather critically by NGOs and experts. The Asian Development Bank and World Bank stand out since experts have more confidence than other audiences. Finally, regional organizations are least popular among citizens compared to all other elite groups, which ties in with recent public research diagnosing a "crisis of trust" in regional institutions [37]. However, there is some institution-specific variation, with SAARC standing out as having relatively low confidence across all audience types. 

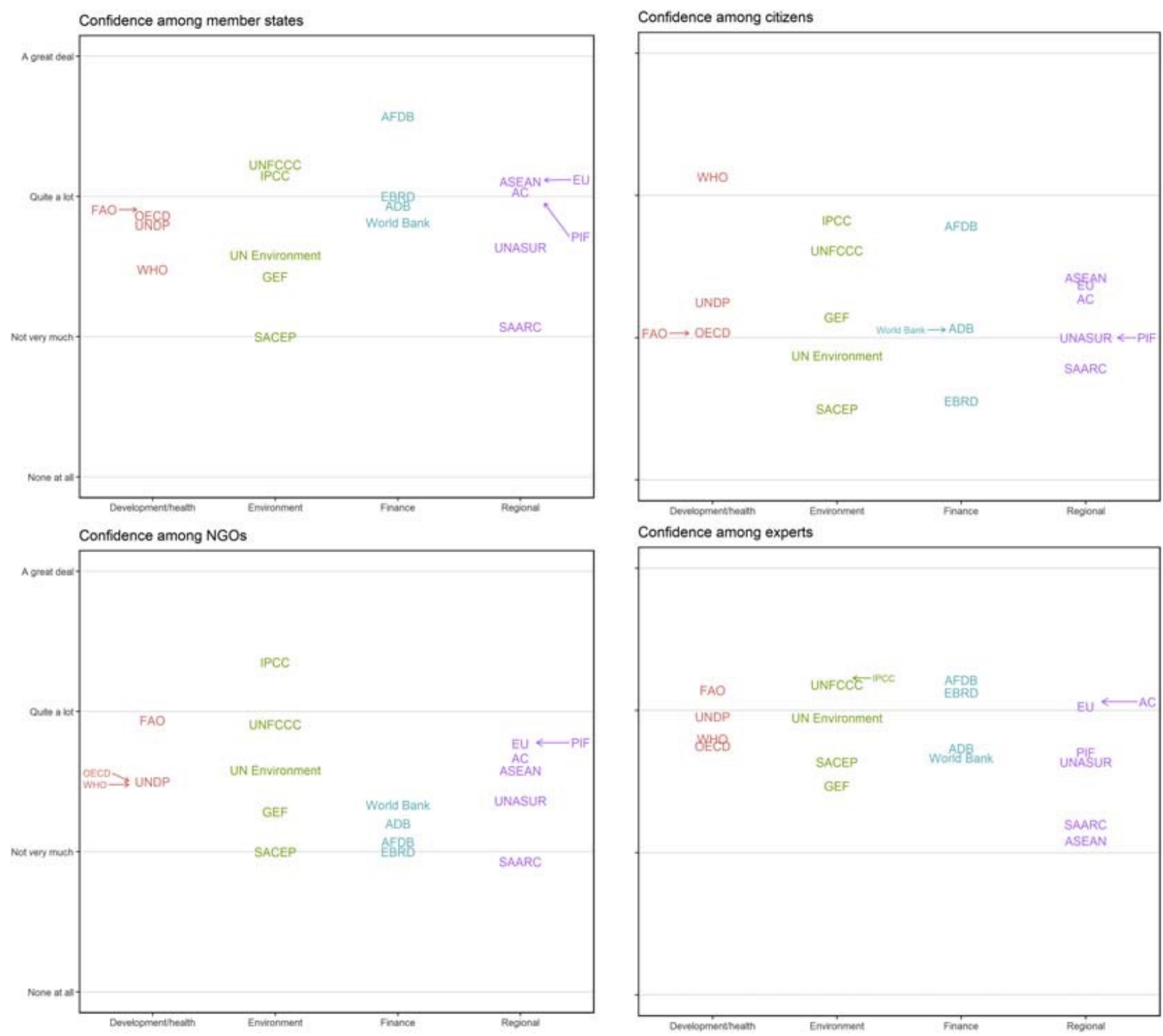

Figure 42.2: Mean confidence across international institutions and stakeholders. 0 (no confidence at all), 1 (not very much confidence), 2 (quite a lot of confidence), 3 (a great deal confidence).

\subsection{The benefits and risks of legitimacy: a research agenda for sustainability scholars}

To manage the legitimacy challenges shown above, policy makers need to consider the specific benefits - but also risks - implied in different institutional contexts and policy areas.

Two central benefits of legitimacy are reduction of transaction costs and 
willingness to internalize proenvironmental norms. In terms of reduced transaction costs, legitimacy is a form of social capital that reduces transaction costs, which is efficiency-enhancing [38,39]. In this respect, greater trust in institutions has been shown to enhance cooperative behavior and outcomes in local [10] and international institutions [18]. In terms of norms internalization, legitimacy has been shown to make people more willing to obey and defer to the government. More generally, people who trust institutions and policies are more likely to change their beliefs and norms in ways that facilitate proenvironmental behavior change $[40,42]$.

Thus legitimate institutions have to rely less often on coercion or secrecy to enforce compliance, which is less effective and costly [43]. Legitimacy is therefore vital for international institutions that generally lack the tools to enforce compliance [11]. In terms of outcomes, international institutions trusted by state and nonstate actors may be able to raise more funds from their environment [30] and be more likely to receive necessary information on developments on the ground from stakeholders [44].

Conversely, there are two central risks. The first is that legitimacy may make voters less prone to acquiring information $[45,46]$. Institutions that voters trust to generate benefits or do the right thing even if left unattended enjoy greater legitimacy [47], but for this very reason, legitimacy may also be a challenge for marine management. In the absence of public scrutiny, collective action problems may become severe. International decision makers may misuse their leeway to make decisions that benefit them personally, with suboptimal collective outcomes. Second, as Levi et al. [48] notes, "[1]egitimacy does not signify that power will be used to promote the good of the nation or of humanity." Indeed citizens that are relatively uninformed tend to be more susceptible to elite framing of international institutions [49], implying that populist rhetoric may in turn be more likely to undermine legitimacy beliefs.

This brief overview of benefits and risks associated with increased legitimacy points to a research agenda on legitimacy and effectiveness in marine management. Below I list four areas in which sustainability scholars could contribute through their research to enabling better management and foresight of legitimacy challenges in international marine institutions.

1.Legitimacy management. Institutions can actively try to boost their own legitimacy, but NGOs and domestic governments are typically more effective in swaying citizen opinion [49]. Top-down legitimation through actions, speeches, and policies may not be as effective as bottom-up 
legitimation, which occurs when, for example, state or nonstate actors become involved in an international institution, thereby accepting the institution's exercise of power [22]. However, institutional factors such as transparency, fairness, and effectiveness can increase the legitimacy of international institutions in the eyes of citizens [34]. Sustainability scientists could usefully examine how legitimacy could be promoted, and when this has beneficial consequences for compliance and effectiveness. 2.Funding strategies. Well-funded international marine institutions are able to include a greater number of NGOs in their management [50]. This has important implications for how policy makers should manage and seek funding. For example, seeking greater legitimacy among scientists and member states may increase the prospects of funding [30,39]. Yet this assumption may rarely be tenable and the extent to which this is the case is an empirical question that warrants future research.

3.Risks for special interest influence. We still know little about how trust operates at the international level between experts and policy makers [39] as well as between citizens and policy makers [49]. A convincing literature in economics building by Downs [45] has shown that "capture" by interest groups, such as business associations, is a risk in governance, especially when public scrutiny is low [51]. Exploring when and how legitimacy may entail risks for capture in international institutions would be an important contribution to the literature.

4.Legitimacy beliefs. There is a burgeoning literature on legitimacy beliefs among user groups [7], stakeholders [52], and private actors [9] in fisheries and marine institutions. Future research could usefully compare legitimacy beliefs among different stakeholders to fully understand legitimacy challenges and elite!citizen gaps in legitimacy that different institutions struggle with, with implications for compliance and effective marine management.

In sum, sustainability scholars have a role to play in enhancing our knowledge about legitimacy in international marine institutions. This chapter has shown that legitimacy entails both benefits and risks for effective marine management. Using novel expert survey evidence on the legitimacy of 19 international institutions dealing with marine issues, the key finding is twofold. First, there is a striking gap between legitimacy beliefs among elites and citizens toward international marine institutions. Second, there is variation in this elite-citizen gap across institutions, which begs questions of how institution-specific 
legitimacy challenges should be managed to address compliance problems.

Overall, legitimacy research in sustainability science yields the prospects of a better understanding of the legitimacy-effectiveness link in marine management.

\section{Acknowledgment}

I would like to thank Hugo Faber, Alice Fasakin, Ana-Sofia Valderas, and Ognjen Zugic for their excellent research assistance.

\section{References}

[1] Food and Agriculture Organization of the United Nations, The state of world fisheries and aquaculture, Contributing to Food Security and Nutrition for All, FAO, Rome, 2016, pp. $1 ! 200$.

[2] S. Cullis-Suzuki, D. Pauly, Failing the high seas: a global evaluation of regional fisheries management organizations, Mar. Policy 34 (2010) 1036!1042. Available from:

https://doi.org/10.1016/j. marpol.2010.03.002.

[3] O”. Bodin, H. O sterblom, International fisheries regime effectiveness - activities and resources of key actors in the Southern Ocean, Global Environ. Change 23 (2013) 948!956. Available from: https://doi. org/10.1016/j.gloenvcha.2013.07.014.

[4] M. Pons, M.C. Melnychuk, R. Hilborn, Management effectiveness of large pelagic fisheries in the high seas, Fish Fish. 19 (2018) 260!270. Available from: https://doi.org/10.1111/faf.12253.

[5] K.W. Abbott, J.F. Green, R.O. Keohane, Organizational ecology and institutional change in global governance, Int. Organ. 70 (2016) 247!277. Available from:

https://doi.org/10.1017/S0020818315000338.

[6] J. Tallberg, L.M. Dellmuth, H. Agne', A. Duit, NGO influence in international organizations: information, access and exchange, Brit. J. Polit. Sci. 48 (2018) 213!238. Available from: https://doi.org/10.1017/ S000712341500037X.

[7] S. Jentoft, Legitimacy and disappointment in fisheries management, Mar. Policy. 24 (2000) 141!148. Available from: https://doi.org/10.1016/S0308-597X(99)00025-1.

[8] E. Pinkerton, L. John, Creating local management legitimacy, Mar. Policy 32 (2008) 680!691. Available from: https://doi.org/10.1016/j.marpol.2007.12.005.

[9] A. Kalfagianni, P. Pattberg, Exploring the output legitimacy of transnational fisheries governance, Globalizations 11 (2014) 385!400. Available from:

https://doi.org/10.1080/14747731.2014.888305.

[10] J. Piwowarczyk, B. Wro bel, Determinants of Legitimate Governance of Marine Natura 2000 Sites in a Post-Transition European Union Country: A Case Study of Puck Bay, Poland, 2016. ,https://doi.org/ 10.1016/j.marpol.2016.01.019..

[11] I. Hurd, Legitimacy and authority in international politics, Int. Org. 53 (1999) $379 ! 408$.

[12] $\mathrm{O}$. Bodin, Collaborative environmental governance: achieving collective action in 
social-ecological systems, Science 357 (2017) eaan1114. Available from: https://doi.org/10.1126/science.aan1114.

[13] R. Parmentier, Role and impact of international NGOs in global ocean governance, Ocean Yearbook Online 26 (2012) 209!229.

[14] I. Sakaguchi, The roles of activist NGOs in the development and transformation of IWC regime: the interaction of norms and power, J. Environ. Stud. Sci. 3 (2013) 194!208. Available from: https://doi.org/ 10.1007/s13412-013-0114-3.

[15] T. Skodvin, S. Andresen, Nonstate influence in the International Whaling Commission, 1970!1990, in: M.M. Betsill, E. Corell (Eds.), NGO Diplomacy: The Influence of Nongovernmental Organizations in International Environmental Negotiations, MIT Press, Cambridge, 2008, pp. 119!148.

[16] K. Orach, M. Schlu“ter, H. O” sterblom, Tracing a pathway to success: how competing interest groups influenced the 2013 EU Common Fisheries Policy reform, Environ. Sci. Policy 76 (2017) 90!102. Available from: https://doi.org/10.1016/j.envsci.2017.06.010.

[17] C. Coffey, What role for public participation in fisheries governance? in: T.S. Gray (Ed.), Participation in Fisheries Governance, Springer, Dordrecht, 2005, pp. 27 !54.

[18] R.O. Keohane, D.G. Victor, Cooperation and discord in global climate policy, Nat. Clim. Change 6 (2016) 570!575. Available from: https://doi.org/10.1038/nclimate2937.

[19] M. Weber, Economy and Society, University of California Press, Berkeley, CA, 1922 [1978].

[20] B. Gilley, The Right to Rule: How States Win and Lose Legitimacy, Columbia University Press, New York, 2009.

[21] J. Steffek, Why IR needs legitimacy: a rejoinder, Eur. J. Int. Rel. 10 (2004) 485!490. Available from: https://doi.org/10.1177/1354066104045545.

[22] J. Tallberg, K. Ba ckstrand, J.A. Scholte (Eds.), Legitimacy in Global Governance: Sources, Processes, and Consequences, Oxford University Press, Oxford, 2018.

[23] D. Beetham, The Legitimation of Power, Macmillan, London, 1991.

[24] A. Buchanan, R.O. Keohane, The legitimacy of global governance institutions, Ethics Int. Aff. 20 (2006) 405!437. Available from: https://doi.org/10.1111/j.17477093.2006.00043.x.

[25] I. Hurd, After Anarchy. Legitimacy and Power in the United Nations Security Council, Princeton University Press, Princeton, NJ, 2007.

[26] L.M. Dellmuth, J. Tallberg, The social legitimacy of international organisations: interest representation, institutional performance, and confidence extrapolation in the United Nations, Rev. Int. Stud. 41 (2015) 451!475. Available from: https://doi.org/10.1017/S0260210514000230.

[27] M.C. Suchman, Managing legitimacy: strategic and institutional approaches, Acad. Manage. Rev. 20 (1995) 571!610. Available from: https://doi.org/10.2307/258788.

[28] T. Macdonald, Political legitimacy in international border governance institutions, Eur. J. 
Polit. Theor. 14 (2015) 409!428. Available from:

https://doi.org/10.1177/1474885115589875.

[29] M. Binder, M. Heupel, The legitimacy of the UN Security Council: evidence from recent general assembly debates, Int. Stud. Q. 59 (2015) 238!250. Available from: https://doi.org/10.1111/isqu.12134.

[30] T. Sommerer, H. Agne', Consequences of legitimacy in global governance, in: J. Tallberg, K. Bäckstrand, J.A. Scholte (Eds.), Legitimacy in Global Governance: Sources, Processes, and Consequences, Oxford University Press, Oxford, 2018.

[31] L.M. Dellmuth, Individual sources of legitimacy beliefs: theory and data, in: J. Tallberg, K. Ba"ckstrand, J.A. Scholte (Eds.), Legitimacy in Global Governance: Sources, Processes, and Consequences, Oxford University Press, Oxford, 2018.

[32] M.K. Jennings, Ideological thinking among mass publics and elites, Public Opin. Q. 56 (1992) 419 ! 441 .

[33] Z. Bakaki, T. Bernauer, Do global climate summits influence public awareness and policy preferences concerning climate change? Environ. Polit. 26 (2017) 1!26.

[34] L.M. Dellmuth, J.A. Scholte, J. Tallberg, Institutional sources of legitimacy for international organizations: beyond procedure versus performance, Rev. Int. Stud. (2019) 1!20. https://doi.org/10.1017/S026021051900007X.

[35] L. Kemp, A systems critique of the 2015 Paris agreement on climate, in: M. Hossain, R. Hales, T. Sarker (Eds.), Pathways to a Sustainable Economy, Springer, Cham.

[36] D. Bodansky, The Paris climate change agreement: a new hope? Am. J. Int. Law 110 (2016) 288!319. Available from: https://doi.org/10.5305/amerjintelaw.110.2.0288.

[37] C. Foster, J. Frieden, Crisis of trust: socio-economic determinants of Europeans' confidence in government, European Union Politics, Online First 2017. ,https://doi.org/10.1177/1465116517723499..

[38] E. Weede, Legitimacy, democracy and comparative economic growth reconsidered, Eur. Sociol. Rev. 12 (1996) 217!225. Available from: https://doi.org/10.1093/oxfordjournals.esr.a018189.

[39] J. Lacey, M. Howden, C. Cvitanovic, R.M. Colvin, Understanding and managing trust at the climate science-policy interface, Nat. Clim. Change 8 (2018) 22!28. Available from: https://doi.org/10.1038/ s41558-017-0010-z.

[40] J.A. Joireman, P.A.M. van Lange, M. van Vugt, A. Wood, T.V. Leest, C. Lambert, Structural solutions to social dilemmas: a field study on commuters' willingness to fund improvements in public transit, J. Appl. Soc. Psychol. 31 (2001) 504!526. Available from: https://doi.org/10.1111/j.1559-1816.2001.tb02053.x.

[41] S. Matti, Sticks, carrots and legitimate policies: effectiveness and acceptance in Swedish environmental public policy, in: P. Soderholm (Ed.), Environmental Policy and Household Behaviour: Sustainability and Everyday Life, Earthscan, James \& James, London, 2010, pp. $69 ! 98$.

[42] S. Linde, Political communication and public support for climate mitigation policies: a 
country-comparative perspective, Clim. Policy 18 (2017) 543!555. Available from: https://doi.org/10.1080/14693062.2017.1327840.

[43] T. Franck, The Power of Legitimacy Among Nations, Oxford University Press, Oxford, 1990.

[44] K.P. Coleman, International Organisations and Peace Enforcement: The Politics of International Legitimacy, Cambridge University Press, Cambridge, 2007.

[45] A. Downs, An Economic Theory of Democracy, Cambridge University Press, Cambridge, 1957.

[46] B. Caplan, The Myth of the Rational Voter, Princeton University Press, Princeton, NJ, 2007.

[47] D. Easton, A re-assessment of the concept of political support, Br. J. Polit. Sci. 5 (1975) 435!457. Available from: https://doi.org/10.1017/S0007123400008309.

[48] M. Levi, A. Sacks, T.R. Tyler, Conceptualizing legitimacy, measuring legitimating beliefs, Am. Behav. Sci. 53 (2009) 354!375. Available from: https://doi.org/10.1177/0002764209338797.

[49] L.M. Dellmuth, J. Tallberg, Elite communication and popular legitimacy in global governance. Available at SSRN: ,https://ssrn.com/abstract 52757650. or ,https://doi.org/10.2139/ssrn.2757650., 2018.

[50] L.M. Dellmuth, M.T. Petersson, D. Dunn, A. Boustany, P. Halpin, Drivers of NonGovernmental Organization Participation in Regional Fisheries Management are Institutional, 2018 (Unpublished paper).

[51] S. Singleton, Co-operation or capture? The paradox of co-management and community participation in

natural resource management and environmental policy-making, Environ. Policy 9 (2000) $1 ! 21$.

[52] [53] C. Pare's, J. Dresdner, H. Salgado, Who should set the total allowable catch? Social preferences and legitimacy in fisheries management institutions, Mar. Policy 54 (2015) 36!43. Available from: https:// doi.org/10.1016/j.marpol.2014.12.011.M.R. Steenbergen, G. Marks, Evaluating expert judgments, Eur. J. Polit. Res. 46 (2007) 347-366. 


\section{Appendix}

\section{Appendix A: Completion rates}

\begin{tabular}{|c|c|c|c|c|}
\hline Questionnaire & International organization and acronym & Contacted & Completed & $\begin{array}{l}\text { Completion rate } \\
(\%)\end{array}$ \\
\hline $\begin{array}{l}\text { Arctic Council Asian } \\
\text { Development BankAfrican } \\
\text { Development Bank } \\
\text { Environment } \\
\text { European Bank for } \\
\text { Reconstruction and } \\
\text { DevelopmentFood } \\
\text { Governance } \\
\text { Regional America Regional } \\
\text { Asia } \\
\text { European Union } \\
\text { Development and } \\
\text { humanitarian aid OECD } \\
\text { World Health Organization } \\
\text { World Bank } \\
\text { Total contacted/ completed, } \\
\text { and average completion rate }\end{array}$ & $\begin{array}{l}\text { Arctic Council (AC)Asian Development Bank (ADB) } \\
\text { African Development Bank (AFDB) } \\
\text { Global Environment Facility (GEF), } \\
\text { Intergovernmental Panel on Climate Change (IPCC), } \\
\text { United Nations Framework Convention on Climate } \\
\text { Change (UNFCCC), United Nations Environment } \\
\text { (UN Environment) European Bank for Reconstruction } \\
\text { and Development (EBRD) } \\
\text { Food and Agriculture Organization (FAO)Union of } \\
\text { South American Nations (UNASUR) } \\
\text { Association of Southeast Asian Nations (ASEAN), } \\
\text { South Asia Co-operative Environment Program } \\
\text { (SACEP), South Asian Association for Regional } \\
\text { Cooperation (SAARC), Pacific Islands Forum (PIF) } \\
\text { European Union (EU) } \\
\text { United Nations Development Programme } \\
\text { (UNDP)Organization for Economic Co- operation and } \\
\text { Development (OECD) World Health Organization } \\
\text { (WHO) } \\
\text { World Bank }\end{array}$ & $\begin{array}{l}6655 \\
5168 \\
36 \\
545192 \\
7160 \\
46 \\
79 \\
74803\end{array}$ & $\begin{array}{l}3615 \\
1637 \\
9 \\
141166 \\
3523 \\
16 \\
20 \\
27325\end{array}$ & $\begin{array}{l}54.5527 .27 \\
31.3754 .41 \\
25.00 \\
29.9221 .5771 .74 \\
49.3038 .33 \\
34.7825 .32 \\
36.4936 .52\end{array}$ \\
\hline
\end{tabular}

Notes: Author's own data from expert survey. Completed questionnaires are defined in terms of substantive answers to at least 75\% of the questions. Where natural and social scientists had expertise on more than one international institution, we bundled institutions in one questionnaire and blockrandomized the order in which the questions on a specific institution occur. 
Appendix B: Question wording presented to experts in international marine governance institutions in the order they appear in the questionnaire

The next questions focus on [international organization]. 1. Next

2. I don't have any expertise with regard to this intergovernmental organization.[IF 1, then next questions, otherwise exit questionnaire on this organization.]In your opinion, how much confidence do different stakeholders have in the Arctic Council?

\begin{tabular}{|l|l|l|l|l|l|}
\hline & A great deal & Quite a lot & Not very much & None at all & Don't know \\
\hline $\begin{array}{l}\text { Arctic Council member states Citizens in Arctic } \\
\begin{array}{l}\text { Council member statesNongovernmental } \\
\text { organizations }\end{array}\end{array}$ & 33 & 22 & 11 & 00 & 9999 \\
& 3 & 2 & 1 & 0 \\
\hline
\end{tabular}

We'll finish with some questions about your personal opinions about the Arctic Council and climate change.

How much confidence do you personally have in the Arctic Council?

How important do you personally think it is that the Arctic Council deal with climate risks?

Taking all aspects of the Arctic Council's views on climate risks into account, how close is the Arctic Council to your own personal views on climate risks?

To finish, we would like to ask you a few background questions.

Which type of organization are you employed at?

- $\quad$ Think tank

- $\quad$ Research institute

\begin{tabular}{|c|c|c|c|c|}
\hline $\begin{array}{l}\text { A great } \\
\text { deal }\end{array}$ & Quite a lot & $\begin{array}{l}\text { Not very } \\
\text { much }\end{array}$ & None at all & Don't know \\
\hline 3 & 2 & 1 & 0 & 99 \\
\hline Very important & \multicolumn{2}{|c|}{ Fairly important } & Not very & Not at all \\
\hline
\end{tabular}




\begin{tabular}{|l|l|l|l|}
\hline & & important & important \\
\hline 1 & 2 & 3 & 4 \\
\hline Very close & Fairly close & Not very close & Not at all close \\
\hline 1 & 2 & 3 & 4 \\
\hline
\end{tabular}

- University

- Intergovernmental organization

- If other, please specify: (open text box) How many years of experience with working on intergovernmental organizations or climate change do you have? Please write the years in numbers in the box below. 


\section{Appendix C: Scale reliability checks.}

Expert surveys are designed to generate aggregated ratings. As experts filter their ratings through their personal worldviews and pre-existing knowledge, this appendix assesses the reliability with which they use the answer scales statistically. To test scale reliability, i.e. the degree of uncertainty in the expert perceptions of organizational preferences, we decompose the variance across perceptions of preferences for specific institutions and experts using regression analysis. The regression model can be written as follows:

$\mathrm{Y}_{i k}=\mu+\delta_{k+} \varepsilon_{i k}$

where $\mu$ is the grand mean of perceptions of preferences, and $\delta_{k}$ as well as $\delta_{i k}$ capture institutional and expert effects. Treating $\mu$ as a fixed effect and $\delta_{k}$ as well as $\delta_{i k}$ as random effects, the variance component model reported in Table 2 takes the following form:

$V\left[y_{i j}\right]=\sigma_{\delta}^{2}+\sigma_{\varepsilon i}^{2}$

where $\sigma_{\delta}^{2}$ is the cross-institutional variation in perceptions and $\sigma_{\varepsilon i}^{2}$ is the cross-expert variance.

The key result of this variance component analysis for the different confidence items is that the size of the expert-specific variation is quite limited (see Table $\mathrm{C} 1$ ). The estimated expert variance is only statistically significant with regard to one of the four items. Moreover, the size of this variation is relatively small: the estimated standard deviation is around 0.7 on the 4-point confidence scale. These results indicate that the larger share of experts renders quite similar judgments about organizational preferences. Moreover, as expected, cross-institutional variation is substantial given that the cross-institutional variance is statistically significant for all confidence items.

On the basis of the regression estimates in the variance component analysis in Table C1, we calculate the reliability of expert ratings via the Spearman-Brown formula using the average number of experts [1]. The reliability coefficients are above 0.8 , indicating a very high reliability. ${ }^{1}$

\section{References}

[1] M.R. Steenbergen, G. Marks, Evaluating expert judgments, Eur. J. Polit. Res. 46 (2007) $347-366$.

\footnotetext{
${ }^{1}$ The Spearman-Brown formula is computed as $n r[1+(n-1) r]$, where $r$ is the inter-expert correlation from the variance components model and $n$ is the average number of experts (Steenbergen and Marks 2007, p. 363).
} 
Table C1. Variance components analysis of expert ratings of stakeholder confidence

\begin{tabular}{lllll}
\hline Estimated parameter & $\begin{array}{l}\text { Confidence among } \\
\text { member states }\end{array}$ & $\begin{array}{l}\text { Confidence among } \\
\text { citizens }\end{array}$ & $\begin{array}{l}\text { Confidence among } \\
\text { NGOs }\end{array}$ & $\begin{array}{l}\text { Confidence among } \\
\text { experts }\end{array}$ \\
\hline $\begin{array}{l}\text { Fixed effects } \\
\text { Grand mean } \mu\end{array}$ & $\begin{array}{l}1.869^{* * *} \\
(0.081)\end{array}$ & $\begin{array}{l}1.236^{* * *} \\
(0.051)\end{array}$ & $\begin{array}{l}1.518^{* * *} \\
(0.084)\end{array}$ & $\begin{array}{l}1.828^{* * *} \\
(0.072)\end{array}$ \\
Variance components & & & & \\
Institutions $\left(\sigma_{\delta}^{2}\right)$ & $0.268^{* *}$ & $0.334^{* * *}$ & $0.279^{* * *}$ & $0.251^{* * *}$ \\
& $(0.082)$ & $(0.080)$ & $(0.079)$ & $(0.059)$ \\
Experts $\left(\sigma_{\varepsilon i}^{2}\right)$ & 0.767 & 0.777 & 0.793 & $0.688^{* * *}$ \\
& $(0.032)$ & $(0.032)$ & $(0.339)$ & $(0.031)$ \\
\hline$N$ (Institutions) & 19 & 19 & 19 & 19 \\
$N$ (Experts) & 323 & 325 & 325 & 359 \\
Log likelihood & -402.774 & -413.876 & -417.407 & -410.257 \\
\hline Reliability & 0.860 & 0.880 & 0.857 & 0.826 \\
\hline
\end{tabular}

Notes: Multilevel models of confidence items (see Appendix B) estimated with maximum likelihood. Coefficients with robust standard errors clustered at the level of institutions. We pooled the data so that the cases are institution-specific expert perceptions, implying that the number of experts is slightly higher than in Table 1. A constant is included in all models but not reported for the sake of brevity. ${ }^{*} p<.05,{ }^{* *} p<.01,{ }^{* * *} p<.001$ 